\title{
Effect of Leukemia Inhibitory Factor and Forskolin on Establishment of Rat Embryonic Stem Cell Lines
}

\author{
Masumi HIRABAYASHI ${ }^{1,2)}$, Teppei GOTO1,3), Chihiro TAMURA ${ }^{1)}$, Makoto SANBO'1), \\ Hiromasa HARA ${ }^{4)}$ and Shinichi HOCHI ${ }^{4,5)}$ \\ ${ }^{1)}$ Center for Genetic Analysis of Behavior, National Institute for Physiological Sciences, Aichi 444-8787, Japan \\ ${ }^{2}$ S) School of Life Science, The Graduate University for Advanced Studies, Aichi 444-8787, Japan \\ ${ }^{3)}$ Graduate School of Bioagricultural Sciences, Nagoya University, Aichi 464-8601, Japan \\ 4) Interdisciplinary Graduate School of Science and Technology, Shinshu University, Nagano 386-8567, Japan \\ ${ }^{5)}$ Faculty of Textile Science and Technology, Shinshu University, Nagano 386-8567, Japan
}

\begin{abstract}
This study was designed to investigate whether supplementation of $2 \mathrm{i}$ medium with leukemia inhibitory factor (LIF) and/or forskolin would support establishment of germline-competent rat embryonic stem (ES) cell lines. Due to the higher likelihood of outgrowth rates, supplementation of forskolin with or without LIF contributed to the higher establishment efficiency of ES cell lines in the WDB strain. Germline transmission competency of the chimeric rats was not influenced by the profile of ES cell lines until their establishment. When the LIF/forskolin-supplemented 2i medium was used, the rat strain used as the blastocyst donor, such as the WI strain, was a possible factor negatively influencing the establishment efficiency of ES cell lines. Once ES cell lines were established, all lines were found to be germline-competent by a progeny test in chimeric rats. In conclusion, both LIF and forskolin are not essential but can play a beneficial role in the establishment of "genuine" rat ES cell lines.
\end{abstract}

Key words: ES cells, Forskolin, Genuine leukemia inhibitory factor (LIF), Rat blastocysts

(J. Reprod. Dev. 60: 78-82, 2014)

$\mathbf{R}$ at embryonic stem (ES) cell lines have been established by using few inhibitors for fibroblast growth factor (FGF) receptor, mitogen activated protein kinase kinase (MEK) and glycogen synthase kinase 3 (GSK3) in differentiation-related signaling pathways [1,2]. This protocol ( $3 \mathrm{i}$ system) and modified protocol without an inhibitor for the FGF receptor (2i system) were found to be reproducible in establishing rat ES cell lines [3-6]. However, it remains unclear which additional supplements are essential or useful for the establishment of germline-competent (= genuine) rat ES cell lines.

Leukemia inhibitory factor (LIF) is known to be an essential supplement for establishment of mouse ES cell lines in the classical culture protocol. Establishment of rat ES cell lines has been reported in the presence of LIF [1, 3, 4, 7-9] or absence of LIF [2, 5, 6, 10] under either the $2 \mathrm{i}$ or $3 \mathrm{i}$ system with various rat strains. An inhibitor for Rho-associated coiled-coil kinase (ROCK) and rat serum have been supplemented to LIF-free $2 \mathrm{i}$ culture medium for establishment of rat ES cell lines [5]. Forskolin, an well-known adenylate cyclase stimulator [11], has been used to facilitate establishment of ES cell lines in humans [12] and pigs [13]; the ES cell colonies appeared to be naïve, with biological and epigenetic characteristics similar to those of mouse ES cells. We have recently reported that establishment of germline-competent ES cells from a homozygous

Received: October 16, 2013

Accepted: November 11, 2013

Published online in J-STAGE: December 7, 2013

(C)2014 by the Society for Reproduction and Development

Correspondence: M Hirabayashi (e-mail: mhirarin@nips.ac.jp)
CAG/Venus transgenic rat line was possible only when both LIF and forskolin were supplemented into the $2 \mathrm{i}$ culture medium [14], but the experimental scale was too small to lead a certain conclusion. Thus, a systematic experimental design would be required to analyze the substantial importance of these supplements in establishment of germline-competent rat ES cell lines.

An experiment was conducted to investigate whether supplementation of $2 \mathrm{i}$ medium with LIF and/or forskolin could support establishment of germline-competent rat ES cell lines in a $2 \times 2$ factorial design. The establishment efficiency of ES cell lines in the WDB rat strain was significantly increased by forskolin supplementation ( $88-94 \%$ vs. $50 \%$ in $2 \mathrm{i}$ medium alone; Table 1), probably due to the higher likelihood of outgrowth rate in forskolin-supplemented medium ( $88-94 \%$ vs. $62 \%$ in $2 \mathrm{i}$ medium alone). No obvious difference in the morphology of the ES cell colonies was detected among the 4 groups. Establishment efficiencies of rat ES cell lines reported so far have been variable, such as $23-70 \%$ and $16-79 \%$ in LIF-supplemented $2 \mathrm{i}$ medium $[1,7-9,15,16]$ and LIF-free $2 \mathrm{i}$ medium $[2,5,10]$, respectively. No difference in gender ratio (male:female) of the established ES cell lines was found among the 4 groups $(3: 10,5: 8$, $5: 4$ and $6: 5$ in the no supplement group, LIF group, forskolin group and LIF/forskolin group, respectively).

To facilitate analysis of germline-transmission competency of the ES cell lines, only the ES cell lines with male gender ( 3 each) were used for production of chimeric rats. During the process of chimeric rat production, a significantly lower offspring rate from ES-cell-injected blastocysts was noted in the LIF/forskolin group when compared with the other 3 groups (15-31\% vs. 35-82\%; 
Table 1. Establishment of rat ES cell lines in 2i medium supplemented with LIF and/or forskolin

\begin{tabular}{ccccc}
\hline LIF & Forskolin & $\begin{array}{c}\text { Blastocysts } \\
\text { seeded }\end{array}$ & $\begin{array}{c}\text { Blastocysts } \\
\text { outgrown (\%) }\end{array}$ & $\begin{array}{c}\text { ES cell lines } \\
\text { established }(\%)\end{array}$ \\
\hline- & - & 26 & $16(62)^{\mathrm{a}}$ & $13(50)^{\mathrm{a}}$ \\
+ & - & 17 & $15(88)^{\mathrm{ab}}$ & $13(76)^{\mathrm{ab}}$ \\
- & + & 16 & $14(88)^{\mathrm{ab}}$ & $14(88)^{\mathrm{b}}$ \\
+ & + & 17 & $16(94)^{\mathrm{b}}$ & $16(94)^{\mathrm{b}}$ \\
\hline
\end{tabular}

a,b Different superscripts denote significant differences within columns $(\mathrm{P}<0.05)$.

$\mathrm{P}<0.05$, Table 2), but the overall efficiency of producing chimeric rats was comparable among the 4 groups. Male chimeric rats with a relatively high contribution of the WDB characteristics in coat color have been preferentially used for progeny test [14]. However in the present study, all surviving chimeric male rats with chimerism of $5-95 \%$ in coat color were used for analysis of germline transmission (see Supplementary Fig. 1: available online).

Germline transmission competency of the chimeric rats $(67-100 \%$ of cell lines analyzed) was not affected by the profile of ES cell lines until their establishment (Table 2). Individual data concerning the proportion of ES rats per G1 offspring were uploaded as supplementary data (see Supplementary Table 1: available online). An earlier report [1] described the low germline competence of rat ES cells established in LIF-supplemented $2 \mathrm{i}$ medium $(25 \%)$, while recent studies [7, 9] indicated that high frequencies of rat ES cell lines established in LIF-supplemented $2 \mathrm{i}$ medium were germline-competent (71-80\%). It has been reported that forskolin is effective in improving the baseline level of pluripotency in human and porcine ES cells $[12,13]$. In addition, the limited capacity of rabbit induced-pluripotent stem cells to differentiate into glial oligodendrocytes has been overcome by converting the stem cells to a naïve state with forskolin [17]. Although no parameters for growth rate in cultures were investigated in the present study, both rat LIF and forskolin may be useful in stimulating self-renewal of naïve stem cells.
RT-PCR analysis indicated that stem cell markers such as Oct-4, rNanog, Fgf-4 and Rex-1 were expressed in all 12 rat ES cell lines examined (Fig. 1). Even ES cell lines that are not germline-competent (ID: B-3 and C-2) have been shown to express these genes at comparable levels in the other lines, suggesting that expression of the stem cell markers is not a useful parameter to predict the germline competency of rat ES cell lines. Weak expression of Gata6 was detected in all the rat ES cell lines, as a certain expression of Gata6 has been reported in rat ES cells $[1,18]$. In addition, all the rat ES cells expressed the $\mathrm{Cdx} 2$ gene, as reported in genuine rat ES cells [8]. The expression of Gata 6 and $\mathrm{Cdx} 2$ may be a unique characteristic of the rat ES cells.

An additional experiment was conducted to investigate whether four different rat strains (WDB and WI with or without gene modification) influence to the establishment efficiency of ES cell lines. The Wistar strain is the most conventionally used rat strain (closed colony) in the field of neuroscience, but it is a minor strain in stem cell research. When the LIF/forskolin-supplemented $2 \mathrm{i}$ medium was used for culture of blastocysts, rat strains such as the WI strain were less effective than the WDB strain in terms of establishment efficiency (59 vs. 94\%; Table 3). Gene modification itself seemed not to be a negative factor for the establishment efficiency, but it is impossible to emphasize the above description as a general conclusion because of the limited number of transgenic strains tested here. Once ES cell lines were established, all lines $(100 \%, 7 / 7$ in overall) were found to be germline-competent by a progeny test in chimeric rats. Efficiency of producing chimeric rats by blastocyst injection of the ES cells varied among the rat strains $(6-33 \%$ in overall; Table $3)$. The combination of the genetic background of the ES cells and the host blastocysts has been demonstrated to be a critical factor affecting the efficiency of producing chimeric rats and the germline competency of the ES cells [19].

It is concluded that both LIF and forskolin are not essential but can play a beneficial role in the establishment of "genuine" rat ES cell lines.

Table 2. Production of chimeric rats with ES cells and their ability for germline transmission

\begin{tabular}{|c|c|c|c|c|c|c|c|}
\hline \multirow{2}{*}{ LIF } & \multirow{2}{*}{ Forskolin } & \multirow{2}{*}{ ES cell line ID } & \multicolumn{3}{|c|}{ Efficiency of producing chimeras } & \multicolumn{2}{|c|}{ Chimeras } \\
\hline & & & Injected & Pups born $(\%)$ & Chimeras $(\%)$ & Analyzed & GT positive* $(\%)$ \\
\hline \multirow[t]{3}{*}{-} & - & A-1 & 58 & $34(59)$ & $24(71)$ & 8 & $3(38)$ \\
\hline & & A-2 & 45 & $29(64)\} a^{*}$ & $8(28)$ & 5 & $2(40)$ \\
\hline & & A-3 & 63 & $31(49)$ & $9(29)$ & 4 & $4(100)$ \\
\hline \multirow[t]{3}{*}{+} & - & B-1 & 88 & $54(61)$ & $46(85)$ & 13 & $11(85)$ \\
\hline & & B-2 & 36 & $20(56)\} a^{*}$ & $5(25)$ & 4 & $1(25)$ \\
\hline & & B-3 & 34 & $28(82)$ & $11(39)$ & 5 & $0(0)$ \\
\hline \multirow[t]{3}{*}{-} & + & $\mathrm{C}-1$ & 60 & $21(35)$ & $13(62)$ & 9 & $4(44)$ \\
\hline & & $\mathrm{C}-2$ & 51 & $31(61)\} a^{*}$ & $21(68)$ & 14 & $0(0)$ \\
\hline & & C-3 & 59 & $30(51)$ & $13(43)$ & 6 & $3(50)$ \\
\hline \multirow[t]{3}{*}{+} & + & D-1 & 46 & $7(15)$ & $5(71)$ & 1 & $1(100)$ \\
\hline & & D-2 & 48 & $6(13)\} b^{*}$ & $5(83)$ & 1 & $1(100)$ \\
\hline & & D-3 & 48 & $15(31)$ & $10(67)$ & 6 & $3(50)$ \\
\hline
\end{tabular}

GT: Germline transmission. * Different letters denote significant differences within columns $(\mathrm{P}<0.05)$. 


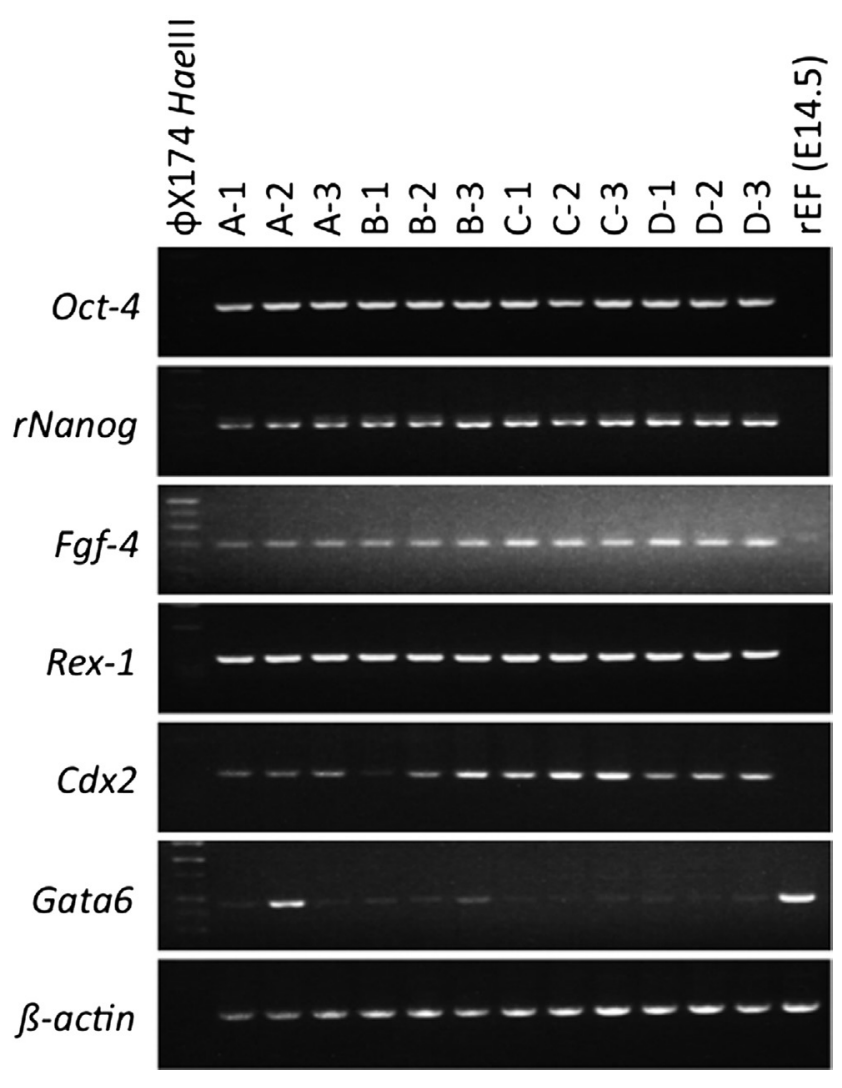

Fig. 1. RT-PCR analysis of 12 rat ES cell lines. Rat embryonic fibroblasts at E14.5 (rEF) serve as the negative control for stem cell markers. As for expression of $\mathrm{Cdx} 2$, colons from day 2 rat offspring and $\mathrm{rEF}$ are used as positive and negative controls, respectively. The IDs of the ES cell lines correspond to those in Table 2.

\section{Methods}

Animals

All procedures for the animal experiment were reviewed and approved by the Animal Care and Use Committee of the National Institute for Physiological Sciences, Okazaki, Japan. Specific pathogen-free rats were purchased from Charles River Laboratories Japan (Kanagawa, Japan). All rats were housed in an environmentally controlled room with a 12-h dark/12-h light cycle at a temperature of $23 \pm 2 \mathrm{C}$ and humidity of $55 \pm 5 \%$ and were given free access to a laboratory diet (CE-2; CLEA Japan, Tokyo, Japan) and filtered water. Black coat color was used to identify WDB (A rat strain "BLK" which we described in previous papers $[14,20,21]$ has been renamed "WDB/ Nips" and registered to Rat Genome Database, http://rgd.mcw.edu/ wg/home, with the RGD ID 7411634). A homozygous CAG/Venus transgenic rat strain, generated with the Crlj:WI background [14], was named "CAG/Venus Tg (WI)." A knock-in rat strain, generated with ES cells originating from the WDB strain [21], was named "RT2 (WDB)".

\section{Establishment of ES cells}

Blastocysts at E4.5 (Fig. 2A) were harvested and freed from their zonae pellucidae. The zona-free blastocysts (Fig. 2B) were cultured for 7 days in (1) $2 \mathrm{i}$ medium consisting of $1 \mu \mathrm{M}$ MEK inhibitor (PD0325901; Stemgent, Cambridge, MA, USA) and $3 \mu \mathrm{M}$ GSK3 inhibitor (CHIR99021; Axon Medchem BV, Groningen, Netherlands) in N2B27 medium [22], (2) $2 \mathrm{i}$ medium with 1,000 U/ml rat LIF (ESGRO $^{\circledR}$; Millipore, Bedford, MA, USA), (3) 2i medium with $10 \mu \mathrm{M}$ forskolin (Sigma-Aldrich, St. Louis, MO, USA), and (4) 2 i medium with $1,000 \mathrm{U} / \mathrm{ml}$ rat LIF and $10 \mu \mathrm{M}$ forskolin on a feeder layer of mitomycin C-treated mouse embryonic fibroblasts. Outgrowths from the blastocysts (Fig. 2C) were disaggregated and transferred to new culture vessels containing the same culture medium (passage-1; P1). These tentative ES cell lines (Fig. 2D) were maintained by medium exchange every other day and trypsinization/expansion every three days (P2 plus). Gender of the ES cell lines was determined by PCR amplification of the rat Y chromosome-specific Sry gene using a REDExtract-N-Amp kit (Sigma-Aldrich). A 104-bp fragment of the rat Sry gene was amplified by 1 cycle for $3 \mathrm{~min}$ at $94 \mathrm{C} ; 38$ cycles for $30 \mathrm{sec}$ at $94 \mathrm{C}, 30 \mathrm{sec}$ at $55 \mathrm{C}$ and $30 \mathrm{sec}$ at $72 \mathrm{C}$; and 1 cycle for $10 \mathrm{~min}$ at $72 \mathrm{C}$ with a primer pair of Sry-F (5'-CAT CGA AGG GTT AAA GTG CCA-3') and Sry-R (5'-ATA GTG TGT AGG TTG TTG TCC-3').

\section{Expression of stem cell marker genes}

The expression of stem cell marker genes (Oct-4, rNanog, Fgf-4

Table 3. Effect of rat strain on ES cell derivation in LIF/forskolin-supplemented 2i medium

\begin{tabular}{|c|c|c|c|c|c|c|c|c|c|c|c|}
\hline \multirow[b]{2}{*}{ Strain (Origin) } & \multicolumn{2}{|c|}{ Blastocysts } & \multicolumn{3}{|c|}{ ES cell lines } & \multicolumn{6}{|c|}{ Profiles for chimera production and progeny test } \\
\hline & Seeded & $\begin{array}{c}\text { Outgrown } \\
(\%)\end{array}$ & $\begin{array}{c}\text { Established } \\
(\%)\end{array}$ & $\begin{array}{c}\text { Analyzed } \\
\text { for GT }\end{array}$ & $\begin{array}{c}\text { Genuine } \\
(\%)\end{array}$ & $\begin{array}{l}\text { ES cell } \\
\text { line ID }\end{array}$ & Injected & $\begin{array}{l}\text { Pups born } \\
(\%)\end{array}$ & $\begin{array}{c}\text { Chimeras } \\
(\%)\end{array}$ & Analyzed & $\begin{array}{c}\text { GT positive } \\
(\%)\end{array}$ \\
\hline \multirow[t]{3}{*}{ WDB* } & 17 & $16(94)^{b}$ & $16(94)^{b}$ & 3 & $3(100)$ & D-1 & 46 & $7(15)$ & $5(71)$ & 1 & $1(100)$ \\
\hline & & & & & & D-2 & 48 & $6(13)$ & $5(83)$ & 1 & $1(100)$ \\
\hline & & & & & & D-3 & 48 & $15(31)$ & $10(67)$ & 6 & $3(50)$ \\
\hline \multirow[t]{2}{*}{ WI } & 17 & $10(59)^{\mathrm{ab}}$ & $10(59)^{\mathrm{ab}}$ & 2 & $2(100)$ & E-1 & 35 & $14(40)$ & $6(43)$ & 2 & $2(100)$ \\
\hline & & & & & & E-2 & 33 & $3(9)$ & $2(67)$ & 1 & $1(100)$ \\
\hline CAG/Venus Tg (WI) & 19 & $8(42)^{a}$ & $8(42)^{a}$ & 1 & $1(100)$ & F-1 & 51 & $17(33)$ & $17(100)$ & 3 & $1(33)$ \\
\hline RT2 (WDB) & 8 & $7(88)^{b}$ & $7(88)^{b}$ & 1 & $1(100)$ & G-1 & 63 & $23(37)$ & $16(70)$ & 8 & $2(25)$ \\
\hline
\end{tabular}

GT: Germline transmission. * Data for WDB are derived from Table 1 and Table 2 (D-1 to -3). ${ }^{\text {a,b }}$ Different superscripts denote significant differences within columns $(\mathrm{P}<0.05)$. 


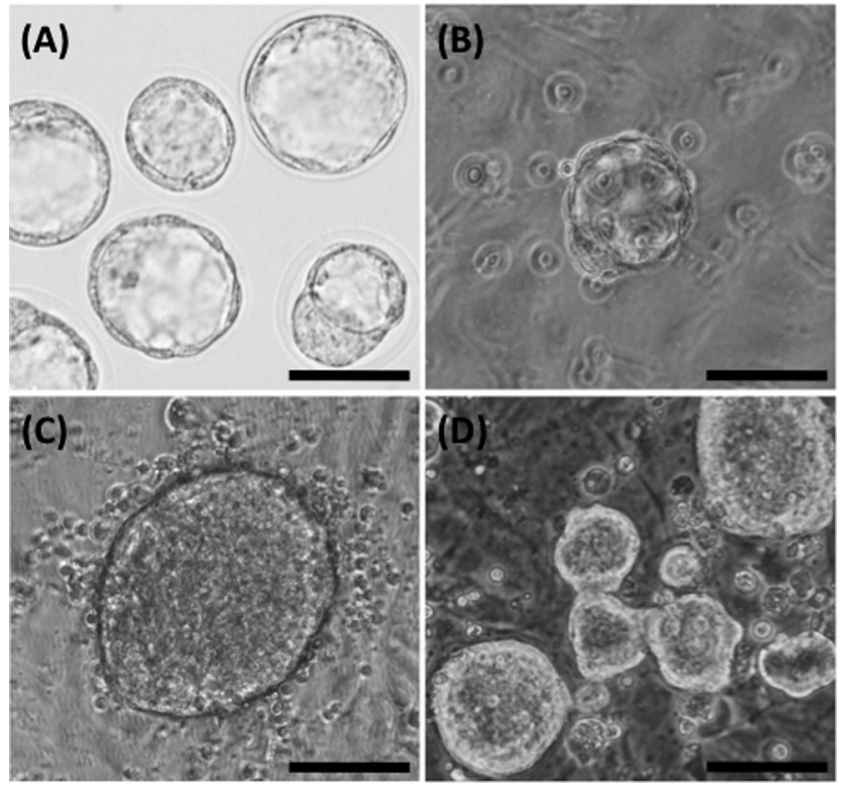

Fig. 2. (A) Rat blastocyst at E4.5. (B) Zona-free blastocyst seeded onto mouse embryonic fibroblasts. (C) Outgrowth of blastocyst after 5 days of culture. (D) ES cell colonies 2 days after 3rd passage. Scale bars: $100 \mu \mathrm{m}$

and Rex-1), a trophectoderm-specific marker gene (Cdx2) and reference genes (Gata6 and $\beta$-actin) was examined by RT-PCR analysis. The primer sets used were the same as those described in our recent publication [23]. Briefly, total RNA was extracted from each sample using a RNeasy ${ }^{\circledR}$ Mini Kit (Qiagen, Germantown, MD, USA). The cDNA was prepared using a Superscript ${ }^{\mathrm{TM}}$ III First-Strand Synthesis System (Invitrogen, Carlsbad, CA, USA) and amplified with TaKaRa LA Taq ${ }^{\circledR}$ (Takara Bio, Shiga, Japan) by 30 cycles at $95 \mathrm{C}$ for $30 \mathrm{sec}$, at $55 \mathrm{C}$ (or $60 \mathrm{C}$ in case of rNanog and Gata6) for $30 \mathrm{sec}$ and at $72 \mathrm{C}$ for $60 \mathrm{sec}$.

\section{Germline transmission}

The potential of each ES cell line for germline transmission was examined by the conventional approach using G1 generation offspring via chimeric rats [3]. Chimeric rats were prepared by microinjection of 10-15 cells from each ES cell line at P5-19 into the blastocoel cavity of WI E4.5 blastocysts, as described previously [18]. When the albino WI-derived ES cells (without fluorescent markers) were used, the host blastocysts were from the WDB female rats. All chimeric male rats that could develop to adulthood were used for the progeny test. Contribution of the ES cells in the resultant offspring was confirmed by their coat color. When germline-competent G1 offspring were not obtained, the progeny test was terminated with the negative data from at least 5 chimeric rats per ES cell line and 4 litters per chimeric rat.

\section{Statistics}

Data regarding the outgrowth rate and the establishment efficiency at P5 were analyzed by Fisher's exact probability test using js-STAR
2012, a program available online (http://www.physics.csbsju.edu/ stats/Index.html). Percentage data regarding the full-term development of ES cell-injected blastocysts, chimeric rat production and germline-competent chimeras were arcsine transformed and analyzed by Fisher's least significant difference test after one-way ANOVA. A value of $\mathrm{P}<0.05$ was chosen as an indication of statistical significance.

\section{Acknowledgments}

The authors thank Mrs Kiyo Itokawa and Keiko Yamauchi (National Institute for Physiological Sciences) for their assistance in animal care and preparation. This work was supported in part by Grants-in-Aid for Scientific Research from the Japan Society for the Promotion of Science (JSPS; 22300147 and 25290037 to MH). $\mathrm{HH}$ is a JSPS Research Fellow.

\section{References}

1. Buehr M, Meek S, Blair K, Yang J, Ure J, Silva J, McLay R, Hall J, Ying QL, Smith A. Capture of authentic embryonic stem cells from rat blastocysts. Cell 2008; 135: 1287-1298. [Medline] [CrossRef]

2. Li P, Tong C, Mehrian-Shai R, Jia L, Wu N, Yan Y, Maxson RE, Schulze EN, Song H, Hsieh CL, Pera MF, Ying QL. Germline competent embryonic stem cells derived from rat blastocysts. Cell 2008; 135: 1299-1310. [Medline] [CrossRef]

3. Hirabayashi M, Kato M, Kobayashi T, Sanbo M, Yagi T, Hochi S, Nakauchi H. Establishment of rat embryonic stem cell lines that can participate in germline chimerae at high efficiency. Mol Reprod Dev 2010; 77: 94. [Medline]

4. Hirabayashi M, Kato M, Sanbo M, Kobayashi T, Hochi S, Nakauchi H. Rat transgenesis via embryonic stem cells electroporated with the Kusabira-orange gene. Mol Reprod Dev 2010; 77: 474. [Medline] [CrossRef]

5. Kawamata M, Ochiya T. Generation of genetically modified rats from embryonic stem cells. Proc Natl Acad Sci USA 2010; 107: 14223-14228. [Medline] [CrossRef]

6. Tong C, Li P, Wu NL, Yan Y, Ying QL. Production of p53 gene knockout rats by homologous recombination in embryonic stem cells. Nature 2010; 467: 211-213. [Medline] [CrossRef]

7. Yamamoto S, Nakata M, Sasada R, Ooshima Y, Yano T, Shinozawa T, Tsukimi Y, Takeyama M, Matsumoto Y, Hashimoto T. Derivation of rat embryonic stem cells and generation of protease-activated receptor-2 knockout rats. Transgenic Res 2012; 21: 743-755. [Medline] [CrossRef]

8. Hong J, He H, Weiss ML. Derivation and characterization of embryonic stem cells lines derived from transgenic Fischer 344 and Dark Agouti rats. Stem Cells Dev 2012; 21 1571-1586. [Medline] [CrossRef]

9. Blair K, Leitch HG, Mansfield W, Dumeau CÉ, Humphreys P, Smith AG. Culture parameters for stable expansion, genetic modification and germline transmission of rat pluripotent stem cells. Biol Open 2012; 1: 58-65. [Medline] [CrossRef]

10. Men H, Bauer BA, Bryda EC. Germline transmission of a novel rat embryonic stem cell line derived from transgenic rats. Stem Cells Dev 2012; 21: 2606-2612. [Medline] [CrossRef]

11. Buck J, Sinclair ML, Schapal L, Cann MJ, Levin LR. Cytosolic adenylyl cyclase defines a unique signaling molecule in mammals. Proc Natl Acad Sci USA 1999; 96: 79-84. [Medline] [CrossRef]

12. Hanna J, Cheng AW, Saha K, Kim J, Lengner CJ, Soldner F, Cassady JP, Muffat J, Carey BW, Jaenisch R. Human embryonic stem cells with biological and epigenetic characteristics similar to those of mouse ESCs. Proc Natl Acad Sci USA 2010; 107: 9222-9227. [Medline] [CrossRef]

13. Fujishiro SH, Nakano K, Mizukami Y, Azami T, Arai Y, Matsunari H, Ishino R, Nishimura T, Watanabe M, Abe T, Furukawa Y, Umeyama K, Yamanaka S, Ema M, Nagashima H, Hanazono Y. Generation of naive-like porcine-induced pluripotent stem cells capable of contributing to embryonic and fetal development. Stem Cells Dev 2013; 22: 473-482. [Medline] [CrossRef]

14. Hirabayashi M, Tamura C, Sanbo M, Kato-Itoh M, Kobayashi T, Nakauchi H, Hochi S. A retrospective analysis of germline competence in rat embryonic stem cell lines. Transgenic Res 2013; 22: 411-416. [Medline] [CrossRef]

15. Zhao X, Lv Z, Liu L, Wang L, Tong M, Zhou Q. Derivation of embryonic stem cells from Brown Norway rats blastocysts. J Genet Genomics 2010; 37: 467-473. [Medline] [CrossRef] 
16. Men H, Bryda EC. Derivation of a germline competent transgenic Fischer 344 embryonic stem cell line. PLoS One 2013; 8: e56518. [Medline] [CrossRef]

17. Honda A, Hatori M, Hirose M, Honda C, Izu H, Inoue K, Hirasawa R, Matoba S, Togayachi S, Miyoshi H, Ogura A. Naive-like conversion overcomes the limited differentiation capacity of induced pluripotent stem cells. J Biol Chem 2013; 288: 26157-26166. [Medline] [CrossRef]

18. Hirabayashi M, Hochi S. Rat embryonic stem cells: establishment and their use for transgenesis. In: Atwood CA (ed.), Methodological Advances in the Culture, Manipulation and Utilization of Embryonic Stem Cells for Basic and Practical Applications. Rijeka: InTech; 2011: 397-410.

19. Tong C, Huang G, Ashton C, Li P, Ying QL. Generating gene knockout rats by homologous recombination in embryonic stem cells. Nat Protocols 2011; 6: 827-844. [Medline] [CrossRef]

20. Hirabayashi M, Tamura C, Sanbo M, Goto T, Kato-Itoh M, Kobayashi T, Nakauchi
H, Hochi S. Ability of tetraploid rat blastocysts to support fetal development after complementation with embryonic stem cells. Mol Reprod Dev 2012; 79: 402-412. [Medline] [CrossRef]

21. Kobayashi T, Kato-Itoh M, Yamaguchi T, Tamura C, Sanbo M, Hirabayashi M, Nakauchi H. Identification of rat Rosa26 locus enables generation of knock-in rat lines ubiquitously expressing tdTomato. Stem Cells Dev 2012; 21: 2981-2986. [Medline] [CrossRef]

22. Ying QL, Smith AG. Defined conditions for neural commitment and differentiation. Methods Enzymol 2003; 365: 327-341. [Medline] [CrossRef]

23. Hirabayashi M, Goto T, Tamura C, Sanbo M, Hara H, Kato-Itoh M, Sato H, Kobayashi T, Nakauchi H, Hochi S. Derivation of embryonic stem cell lines from parthenogenetically developing rat blastocysts. Stem Cells Dev 2013; DOI:10.1089/scd.2013.0200. [CrossRef]. [Medline] 